\title{
ПРАГМАТИЧЕСКИЕ АСПЕКТЫ РОССИЙСКОГО МЕДИЙНОГО СЛОВОТВОРЧЕСТВА
}

\author{
PRAGMATIC ASPECTS OF RUSSIAN MEDIA WORD COINAGE \\ ЛАРИСА РАЦИБУРСКАЯ
}

\begin{abstract}
The article focuses on the specificity of pragmatic aspects of innovations survey in mass media. Special attention is paid to the functional peculiarities of such phenomena as evaluativeness and expressiveness, word-building play based on precedence and polycode innovations. The issues of communicative methods of recipient impact in the sphere of media word creation are also analyzed.
\end{abstract}

Keywords: pragmalinguistics, word coinage, neologisms, mass media, evaluation, expressiveness, precedence, polycode

Лариса Рацибурская, Национальный исследовательский Нижегородский государственный университет им. Н.И. Лобачевского, Нижний Новгород - Россия, racib@yandex.ru

ORCID ID: 0000-0002-9332-050X

Одно из актуальных направлений современной лингвистики прагматический подход к явлениям языка и речи [см. Рацибурская 2018]. Лингвистическая прагматика предполагает изучение функционирования языковых единиц в речи: это „изучение поведения языковых знаков в реальных процессах коммуникации" [Норман 2009: 8] и, в частности, в процессах медийной коммуникации, медийного словотворчества. Современное российское медийное словотворчество характеризуется такими параметрами, как субъективизация (усиление личностного начала), демократизация (сближение книжного и разговорного начал), интеллектуализация (игровая составляющая, интертекстуальность, поликодовость), которые коррелируют с прагматикой медиатекста и своеобразно решают одну из главных задач масс-медиа: задачу речевого воздействия на адресата. Для решения этой задачи медийщики используют различные вербальные и невербальные ресурсы. В этом плане в последние десятилетия особенно активизировались лексико-словообразовательные средства языка и поликодовые PR-технологии, которые являются средством идеологического воздействия на сознание носителей языка. 
Словотворчество - феномен языковой личности, одно из проявлений творческой индивидуальности автора. В „антропоцентрически ориентированной" лингвистике человек рассматривается как активный творец языка, и новообразования отражают определенную модель видения мира, которая создана отдельной языковой личностью [Плотникова 2003].

Многие явления социальной действительности обязаны своим возникновением вербальному моделированию, позволяющему при определенных условиях воздействовать на сознание носителей языка и регулировать их поведение так, как это выгодно владельцам и распространителям информационных ресурсов и потоков [Васильев 2013: 5].

Прагматическая функция новообразований связана с непосредственным воздействием на адресата с целью изменения его ценностно-мировоззренческих установок, ментальных и поведенческих актов.

В современных медиатекстах преобладает скрытая оценочность, то есть умело завуалированное манипулирование массовым сознанием, когда используются скрытые языковые механизмы формирования оценки, в том числе новообразования. В этом отношении показательны новообразования-диминутивы. Использование производящих основ иноязычного характера в сочетании с исконными суффиксами в моделях размерно-оценочного словообразования способствует появлению у новообразований не столько размерной семантики, сколько иронии, негативной, пренебрежительно-уничижительной оценочности:

...наши псевдозвезды знают только две категории: „Я” и „Я и другие”. Даже наши желторотые артистишки этим грешат... („Собеседник” 2014, № 44);

оловянные прокурорчики („Новые Известия” 6.04.2015);

...век звездулек короток, надо уметь заработать, каждый хиток должен быть в цель, как имбирный эль... („Собеседник” 2015, № 42);

Девушка спросила про „молодую элитку”, которая ничего не дает стране, но которой родители обеспечили безбедное существование за счет России („Собеседник" 2015, № 49);

И вот уехавшие, подобно мухам, старательно выискивают в новостном потоке всё, что представляет Россию в максимально грязном свете. Потом радостно вывешивают в своих бложиках („Завтра” 2015, № 45);

Костя Меладзе не человек, а - человечище, композиторище, продюсерище, инженер девичьих душ; заповедная редкость, а не человек („Собеседник” 2016, № 3);

Он весь такой активненький-активненький (радио „Вести FM” 13.12.2016). 
С размерно-оценочными суффиксами могут сочетаться и варваризмы, иноязычные слова, еще не освоенные русским языком: „Олдушка” фотографирует стильно одетых стариков, случайно встреченных на улице („Собеседник” 2015, № 34). По мнению ученых, „создание иронического эффекта является давней и устойчивой функцией диминутивов. Ироническая коннотация диминутивов охватывает целый спектр оттенков отношения" [Фуфаева 2018: 310]. Активизация размерно-оценочного словообразования способствует повышению уровня оценочной тональности медийного текста.

В качестве яркого экспрессивно-оценочного средства выступают и новообразования с разговорными суффиксами женскости, которые присоединяются к заимствованиям:

Спикер Совета Федерации заявила, что население России „ментально готово” к тому, что президентом страны станет женщина... [...] Отметим, что на фоне отдельных сенаторш и депутатш Валентина Ивановна выглядит довольно симпатично. Но насчет ментальной готовности все же может заблуждаться („Собеседник" 2016, № 22);

При Клинтонше было бы хуже (радио „Вести FM” 22.09.2017).

В подобных новообразованиях экспрессия усиливается в результате сочетания иноязычных основ с исконными аффиксами стилистически сниженного характера.

В процессе создания лексико-словообразовательных инноваций в медиатекстах обыгрываются имена ключевых фигур современности, известных политиков и общественных деятелей. Новообразования на базе имен собственных являются ярким средством негативной оценки, граничащей с речевой агрессией:

Ельцин - это наше страшное вчера, мы от него еще не ушли, это не история, ельцинизм живет еще повсюду („Завтра” 2015, № 47);

Тяжелые бусы и прямой взгляд - это Псаки... [...] Но когда кто-то занимается псакингом - выходит куда грубее (т/к „Россия 1” 22.02.2016);

Оценил в телевизоре псакозаменительницу - Мари Харф. Господи, их там явно клонируют! Невзирая на все запреты. Понятное дело, какие тут запреты могут быть, если у США такая потребность в кадрах... („Военное обозрение” 15.05.2015);

Смотри, с какой женоненавистницей я работаю. - Я бы сказал - с хиллариненавистницей (радио „Вести FM” 1.09.2016).

Яркой экспрессией отличаются новообразования на базе иноязычных имен собственных в тех случаях, когда производящие основы ино- 
язычного характера сочетаются с исконными сниженными аффиксами, в частности с суффиксом -щин (a) отвлеченной семантики с оттенком неодобрения:

Наверное, есть некая сущностная аналогия между украинством и нынешней кёнигсберщиной („Литературная газета” 24-30.03.2016, № 12);

Украина победит, когда закончится „обамовщина” („Провинция” 9.12.2015);

Лучше хотя бы предполагать, чем обернется для нас трамповщина, чем оказаться неготовыми к каким-либо действиям Америки („Ironpost” 14.11.2016).

Для некоторых СМИ характерно крайне агрессивное речевое поведение, сознательно построенное на нарушении этических норм и эпатаже, в целях привлечения внимания, создания „скандального” имиджа [Петрова, Рацибурская 2017]. В эпоху информационных войн „антропонимия становится оценкой, часто противоречащей сложившемуся в обществе этическому канону" [Клушина 2002: 53]. В современном обществе чрезвычайно конфликтными являются вопросы дискриминации и вражды на почве национальной принадлежности, политических и идеологических предпочтений, что находит отражение в словообразовательных экспериментах журналистов:

Происходит геттизация русских городов, где нерусские дети с нерусским родным языком ведут себя антисоциально („Наша Версия” 20-26.02.2012, № 7);

Майдауны громят кладбища („Экспресс-газета” 4.04.2014) - контаминация исходных узуальных Майдан и дауны;

Бешенцы Европы. Нашествие мигрантов из Африки может уничтожить европейскую цивилизацию („Новое дело. Нижний Новгород” 10.09.2015) - контаминация исходных узуальных бешеные и беженцы.

Экспрессивизации новообразований способствует вовлечение в медийное словотворчество стилистически сниженных слов (основ), которые сочетаются с книжными и/или заимствованными аффиксами (аффиксоидами). Показателен в этом отношении префиксоид еbро-, который в сочетании с исконными словами стилистически сниженного характера развивает качественную семантику и участвует в формировании негативной оценочности.

Выжимают из тебя пот, чтобы превратить его в брызги шампанского для евродевок („Завтра" 2013, № 24);

У Сноудена тоже мало шансов - „евролеваки” при закулисной поддержке России уже выдвигали его два года назад („Собеседник” 2015, № 35); 
...прежде чем скулить об изъятой с родных просторов еврожратве, следовало бы задуматься, так ли уж была она хороша („Литературная газета” 17-23.12.2015);

...слушай, Владимир, тебя и меня достала вся эта еврошпана („Россия 1”, 9.07.2017).

Экспрессивный характер неузуальных дериватов в медийных текстах делает их ярким средством языковой игры как креативной составляющей современной журналистской практики [Ильясова 2009]. Характерное проявление игровой функции - контаминированные новообразования:

Киевские „псакишвили” от церкви продолжают раскол и бесовство („KM.ru” 18.06.2014) - Псаки + Саакашвили;

От второй клинтономики ждут преференций для среднего класса, ориентации на долгосрочные цели и расширения социальных привилегий („Независимая газета" 13.07.2015) - Клинтон + экономика;

И все происходящее может объясняться одним словом - эрдоганомика („,1-й канал" 13.12.2015) - Эрдоган + экономика;

Успехи в сфере трампономики („Коммерсанть” 10.11.2016) - Трамп + экономика;

Трампокалипсис: Европа шокирована итогами выборов в США („ТВЦ” 09.11.2016) - Трамп + апокалипсис.

Медийные новообразования нередко встречаются в составе прецедентных текстов, в качестве которых выступают фразеологизмы, паремии, крылатые выражения, названия популярных произведений литературы и искусства, расхожие фразы:

Виктор Янукович впал в украйности. Президент Украины продолжил движение в Евросоюз мимо удивленных президентов СНГ (26.10.2013, http://www. kommersant.ru/doc/2329663) - Украина + (впасть в) крайности;

Миропритворческая миссия. На саммите в Минске Владимир Путин и Петр Порошенко говорили на разных языках, используя русский (27.08.2014, http:/ / www.kommersant.ru/doc/2553438) - миротворческая (миссия) + притворяться;

Убедителей не судят. Как Владимир Путин и Франсуа Олланд нашли друг друга („Коммерсантъ” 26.11.2015) - убедить + победителей (не судят);

Очень вузкие места. По каким правилам будут поступать в вузы абитуриенты-2016 („Российская газета” 12.10.2015) - вуз + узкие (места);

Вопросы языконезнания. Как в Кремле проходили занятия по русскому языку („Коммерсантъ” 19.05.2015) - (Вопросы) языкознания (журнал) + незнание;

Битва за урождай. Владимир Путин констатировал, что россияне продолжают активно рождаться и без помощи Минздрава („Коммерсантъ” 07.05.2015) - (битва за) урожай + рождаться; 
Ввиду сложившихся предстоятельств. О предстоящей встрече первоиерархов Русской православной (РПЦ) и Римско-католической церквей вчера объявил глава внешнеполитического ведомства РПЦ митрополит Волоколамский Иларион. („Коммерсанть” 06.02.2016) - предстоящая + (сложившиеся) обстоятельства.

Прагмалингвистический подход к анализу новообразований в письменном тексте вовлекает в свою орбиту использование прописных букв, элементов чужого алфавита, неграфических элементов и под. [Попова 2013]. Русская письменная коммуникация конца XX - начала XXI вв. способствовала оформлению такого направления современного языкознания, как лингвистика креатива. Визуализация коммуникации заставила ученых обратить особое внимание на графодериваты как некие гибриды, образования вербально-иконической природы. К графодериватам относят новообразования, построенные на сознательной модификации, обыгрывании их графо-орфографического оформления.

Классификация графодериватов в настоящее время учитывает различные средства их создания, сочетающиеся в рамках слова:

- элементы одного языка, но разных хронологических срезов (Коммерсантъ);

- разные шрифты в рамках одного алфавита (ПЕНЯйте на себя! ФСН напоминает об ответственности за неуплату налогов)

- разнофункциональные элементы одного языка („Аз'арт” - рубрика об азах искусства В журнале „Огонек”; „СТРОЙ!Материалы” (сеть магазинов);

- элементы разных естественных языков (Не UKRadu! Web-aлизация чиновников, КАSИНО);

- элементы естественного языка и цифры (Ве4ер отдыха);

- элементы естественного языка и идеограммы (Pу\$\$ские идуm! Мурак@ми, єокна) [Попова 2013: 149].

В функционально-прагматическом аспекте выявляется полифункциональная специфика графодериватов, которые выполняют свойственные языковой игре эстетико-эмоциональные, экспрессивно-прагматические функции:

Семейные РАНы российской науки. Академия наук ответила на упреки в семейственности и раздутых штатах („Московский комсомолец” 14.12.2016);

NopasaPAH. Академический погром как симптоматика медийной агонии („Новая газета" 5.07.2013);

U-дар по печени. [...] Также в свекле есть витамин U: благодаря своему липотропному действию способен защитить печень от жирового перерождения („Московский Комсомолец.ru” 10.03.2016);

И депутаты у нас... ненастоящие. И\$ку\$тв€нны€. Восклицают „Россия!”, а на лбу у них... видим клеймо „Ро\$\$ия” („Московский комсомолец” 17-24.07.2013); 
ПРО100 ссорит банкиров. Для банковского приложения УЭК используется система ПРО100 („Нижегородская правда” 08.04.2014);

Не-опера-тивное строительство. Ещё в 2008 году началась разработка проекта, а в 2011-м губернатор Валерий Шанцев объявил, что в ближайшие три года новое здание театра оперы и балета будет построено („Патриоты Нижнего” 25.11.2015).

Анализ результатов медийного словотворчества свидетельствует о зависимости прагматического потенциала новообразований от их структурно-семантической специфики. Так, экспрессивно-воздействующий эффект новообразований узуальных способов словообразования может быть связан с размерно-оценочными суффиксами, с разговорными суффиксами женскости, особенно в наименованиях лиц. Экспрессивно-прагматический эффект усиливается, когда новообразования создаются на базе имен собственных, называющих актуальные фигуры современного социума. При этом неодериваты, созданные способом сложения, могут обозначать лиц, а неодериваты с суффиксами -изм, -щин(a) отвлеченной семантики обозначают определенные социально-политические направления, идеологические течения, связанные с социально значимым лицом. В подобных случаях негативная экспрессия может быть обусловлена как семантикой мотивирующих слов и смысловыми коннотациями, связанными с определенной социальной фигурой, так и негативной оценочностью аффиксов. Экспрессивный эффект возникает и в случае сочетаемости стилистически разнородных компонентов слова. Воздействующий эффект особенно возрастает, когда новообразования создаются неузуальными способами: различными видами контаминации, а также графического словообразования. Многие неодериваты характеризуются ярко выраженным игровым эффектом, в частности, в тех случаях, когда в деривационные процессы вовлекаются прецедентные феномены: прецедентные имена и тексты. Экстремальный характер прагматика новообразований приобретает при их агрессивной направленности, как правило, в процессе создания негативного имиджа политика, общественного деятеля. Современное медийное словотворчество, таким образом, является прагматически влиятельным средством вербального воздействия на массовое сознание членов российского социума.

\section{Библиография}

Васильев А. Д. 2013. Игра в слова: манипулятивные операции в текстах СМИ, Санкт-Петербург: Златоуст.

Ильясова С. В. 2009. Языковая игра в коммуникативном пространстве СМИ и рекламы, Москва: Флинта. 
Клушина Н. И. 2002. Имя собственное на газетной полосе, „Русская речь”, № 1, с. 53-56. Норман Б. Ю. 2009. Лингвистическая прагматика (на материале русского и других славянских языков), Минск: БГУ.

Петрова Н. Е., Рацибурская Л. В. 2017. Язык современных СМИ: средства речевой агрессии, Москва: Флинта: Наука.

Плотникова Л. И. 2003. Словотворчество как феномен языковой личности, Белгород: Издательсво Белгородского государственного университета.

Попова Т. В. 2013. Креолизованные дериваты как элемент русской письменной коммуникаизии рубежа XX-XXI вв., [в:] Т. А. Гридина (ред.), Лингвистика креатива - 1, Екатеринбург: Уральский государственный педагогический университет, с. 147-175.

Рацибурская Л. (ред.) 2018. Социокультурные и лингвопрагматические аспекты современных словообразовательных проиессов: коллективная монография, Москва: Флинта.

Фуфаева И. В. 2018. Диминутивы в русских иронических дискурсах: от дружеской шутки до сарказма, [в:] Т. А. Шарыпина, И. К. Полуяхтова, М. К. Меньщикова (ред.), Национальные коды в языке и литературе. Язык и культура: сборник статей, Нижний Новгород: ДЕКОМ, с. 302-311. 